\title{
PHAGOCYTOSIS IN THE POSTEMBRYONIC DEVELOPMENT OF THE DIPTERA.
}

\author{
VERNON L. KELLOGG.
}

In the most recent considerable ${ }^{1}$ paper on the postembryonic development of an insect of complete metamorphosis, the author lays much stress on the small part which phagocytes play in the breaking down of the larval tissues during the metamorphosis of the insect studied - the little brown ant, Lasius faons. In this respect the author sees in the metamorphosis of Lasius (belonging to the Hymenoptera) a sharp contrast to the metamorphosis of the Diptera, in the best-known example of which, the much-studied Calliphora, phagocytosis plays an all-important part. Korotneff ${ }^{2}$ found in the case of the degeneration of the larval muscles of Tinea (Lepidoptera) that there was no phagocytosis. Rengel, ${ }^{3}$ in studying the changes in the alimentary epithelium of Tenebrio and other Coleoptera, found also no phagocytosis, and Needham, ${ }^{4}$ in a careful study of the flag weevil (Mononychus anulpeculus), similarly found a complete lack of phagocytosis in the histolysis of the larval tissues of this insect. Karawaiew strongly agrees with Korotneff and Rengel in believing that phagocytosis is a phenomenon of postembryonic development associated with the length of time occupied by the metamorphosis. With the blowfly the metamorphosis occupies but a few days; with Tinea, a little more than two weeks; with Tenebrio, several weeks, according to the temperature; and with the ants still

${ }^{1}$ Karawaiew, W. Die nachembryonale Entwicklung von Lasius flavus, Zeitschr. f. wiss. Zool., Bd. lxiv (I 898 ), pp. $3^{8} 5^{-478}$, Pls. IX-XII, and ${ }_{5}$ figs. in text.

${ }^{2}$ Korotneff, A. Histolyse und Histogenese des Muskelgewebes bei der Metamorphose der Insekten, Biol. Centralbl., Bd. xii (1 S92), pp. 261-265.

${ }^{3}$ Rengel, C. Ueber die Veränderungen des Darmepithels bei Tenebrio molitor während der Metamorphose, Zcitschr. f. wiss. Zool., Bd. 1xii (IS96).

${ }^{4}$ Needham, J. G. The Metamorphosis of the Flag Weevil (Mononychus vulpeculus), Biol. Bull., vol. i (r900), pp. I79-19r. 
longer; in the case of Lasius flaw first warm spring days until the beginning of June or even longer. In the case of the insects, like the flies, with a short time devoted to metamorphosis, there must be space made for the new organs as quickly as possible; that is, the old larval organs must get out of the way as soon as may be. The natural process, a gradual degeneration, is a process of long duration, and on that account not sufficient in the case of the flies. Hence, says Karawaiew, there has arisen the barbaric devouring of the tissues by the leucocytes.

It has seemed to me unfortunate that in the study of the postembryonal development of the Diptera so much attention should have been given to the highly specialized Muscidæ and so little to more generalized members of the order. The metamorphosis of Coretha, Culex, and Chironomus has been studied somewhat, but without any approach to that exhaustiveness which characterizes the studies of Weismann, Van Rees, Kowalevsky, ct al., on Calliphora. In the hope of fincling some new light upon these extraordinary phenomena of histolysis and histogenesis which are a part of insect metamorphosis I have undertaken the study of the postembryonic development of two flies belonging to the more generalized Diptera, the Nematocera. One of these flies is Blcpharocera capitata, a member of the strange, small family, Blepharoceridæ, with strangely and strongly modified immature stages, and the other is Holonusia nubiginosa, a giant crane fly (Tipulicla), with simple immature stages. While both of these forms are nematocerous Diptera, and to this extent allied, there is an exceptionally wide divergence between them in point of structure of the larval stages, and this difference has, to my mind, an all-important influence in determining the obvious and suggestive differences in the character of the development, which, we shall see, obtains. This present reference to the metamorphosis of these two dipterous forms has to do solely with the peculiarly interesting and suggestive conditions of the histolytic processes in the metamorphosis. 
The larva of Holorusia mbiginosa ${ }^{1}$ is cylindrical, wormlike, tapering slightly towards both ends, without feet or other special organs of locomotion. It attains a length of three inches (outstretched full-grown specimens). The head is a retractile, strongly chitinized capsule, with biting mouthparts. The internal anatomy is simple. The musculation consists, except in the head, of simple segmental, longitudinal, integumental muscles and of annulate integumental muscles. Locomotion is a simple squirming or wriggling, caused by longitudinal contractions. The alimentary canal is a straight tube divisible into the usual parts. The ventriculus has four diverticula or caca, and the large intestine has a single forward projecting diverticulum. There are four Malpighian tubules. There is a single pair of large salivary glands, each gland bent double. The respiratory system consists of a single pair of large spiracles situated on the posterior aspect of the last abdominal segment, and of a pair of main longitudinal tracheal trunks with their branches. The larval life lasts several weeks.

The pupa is found in the same place inhabited by the larva, and is of simple character. It is from one and one-fourth to one and three-fourths inches long. There is a pair of slender, short respiratory tubes on the prothorax. The pupal stage lasts twelve days.

In the course of the postembryonic development of Holorusia I have found no occurrence of phagocytosis. The breaking down of the muscles and salivary glands and fat body of the larva (tissues in which phagocytosis most certainly occurs if at all and in which it is most readily determinable) is accomplished apparently entirely by simple "selbständige Degencration" (Karawaiew). The breaking clown of the muscles does not begin until after the pupal life is well started. In fact there is no very great breaking down essential. The musculation of the adult differs from that of the larva more in the addition of the wing and leg muscles of the thorax

1 This is the first published reference to the immature stages of this giant tipulid. The larvæ were found abundantly on the banks of a small stream near this university (Stanford), lying in mud and slime composed of decaying leaves. 
and the muscles of the head than in any complete substitution of an imaginal musculation for a previous wholly different complex larval musculation. In pupæ one-third through their existence (four days old) a great deal of the larval musculation still persists side by side with the developing new muscles of the thorax. The nuclei of the degenerating larval muscles show the "old-age" characters of degenerating nuclei; the contractile substance first loses its striate appearance, then becomes loosely fibrous, then spongy, and finally breaks up.

The degeneration of the large salivary glands is easily followed. In the larvæ the nuclei of the large epithelial cells
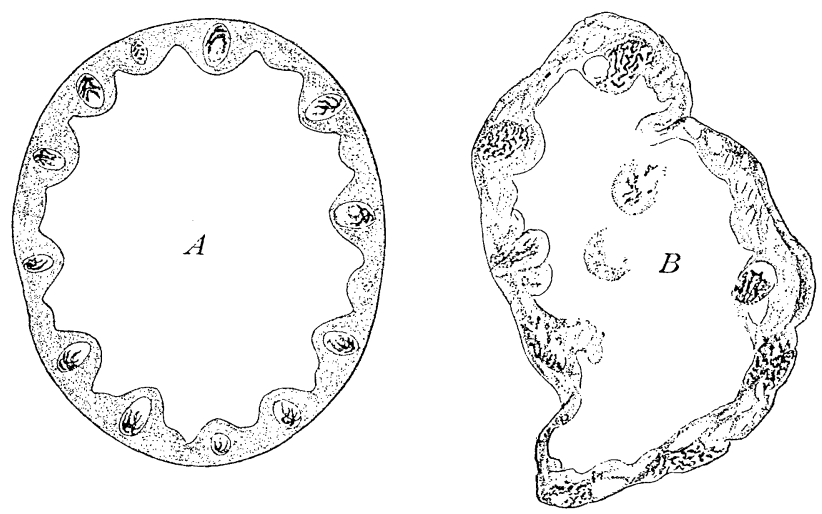

FIG. I. - Salivary gland of Holorusia rubiginosa: $A$ cross-section of gland of larva ; $B$, crosssection of gland in pupa forty-eight hours old, degeneration being well advanced.

are regularly circular or elliptical (in optical plane) and sharply delimited by a nuclear membrane. The chromatin is rather massed together and stains strongly. The cytoplasm of the cells is evenly granular and the cell outlines well defined (Fig. I, $A$ ). In a pupa not more than twenty-four hours old a marked degeneration of the cells has occurred. The cytoplasm is distinctly vacuolated, and in a pupa a clay or two older the cytoplasm is spongy, the cells have lost their shape, the nuclei have lost their membranes and are showing other degenerative characters (Fig. I, B). No phagocytes appear. The degeneration or histolysis of the larval tissues of Holorusia is accomplished thus without the interference of phagocytes. The pupal condition is characterized by no such extensive breaking down 
of larval organs as is apparent in the pupæ of Calliphora, where the pupal body cavity is filled with " pseudo-yolk," a confused fluid mass of degenerating tissue.

The larvæ of Blepharocerc capitata ${ }^{1}$ are of extraordinary external appearance, and in their habits and structure are widely removed from other dipterous larvæ. They live under water in brooks, clinging by six elaborately developed ventral suckers to the smooth rock bed or to smooth stones in parts of the stream where the water runs swiftly and is shallow. The segments of the body are greatly modified, the three thoracic segments and the head being fused to form a single large anterior body region. For the control of the suckers and for the peculiar lateral swinging movement of the body in locomotion an elaborate musculation is developed, which is very different from the musculation of the adult fly. The pupæ are also extraordinary in character and live, like the larvæ, attached to the rocks in swift, shallow parts of the stream. The

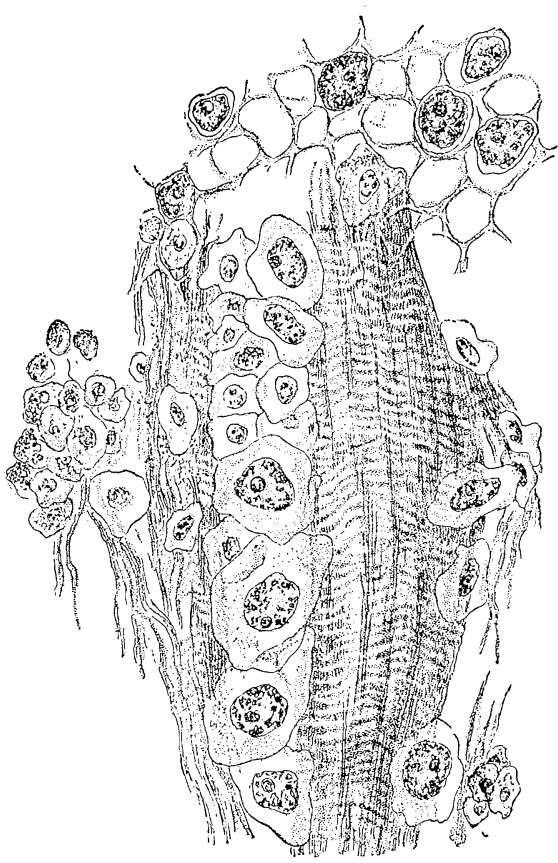

FIG. 2. - Larval muscle of Blepharocera capitata, attached by phagocytes, in a pupa a few days old. duration of the pupal stage is fifteen days. The histolysis of the larval tissues begins three or four days before the true pupal condition is reached. The larva cease feeding, become quiet, and thus remain three or four days before pupation. The total duration, therefore, of the time devoted especially to the change from larva to imago is about eighteen days, as compared with twelve in the case of Holorusia.

1 For an account of the structural character of the larvæ, see Kellogg, Notes on the Life-History and Structure of Blepharocera capitata Loew, Ent. News, vol. xi (r 900), pp. 305-318. 
There is a great breaking down of the larval organs of Blepharocera. With such a specialized larval life there is a great difference between the larval organs and the imaginal organs. The musculature, the alimentary canal, and the respiratory system are largely broken down and reformed. And in all of this histolysis phagocytes are abundant and conspicuous. When pupæe not more than three or four days old are dissected, the body cavity is found to be filled with "pseudo. yolk," that is, with a lymph-like liquid containing floating bits of degenerating tissue and hosts of phagocytes. A bit of larval muscle (Fig. 2) in a pupa a few days old shows very well the character and effects of the phagocytosis.

Thus in the fly Blepharocera, with its eighteen days of prepupal and pupal condition, phagocytosis is conspicuously present; in the fly Holorusia, with its twelve days of pupal condition, histolysis is unaccompanied by phagocytosis. The fly in which the histolytic phenomena occupy the longer time is the one in which the histolysis is accompanied by phagocytosis. This is a condition not at all in consonance with Karawaiew's conclusions, as quoted at the beginning of this paper.

What is the reason for the presence of phagocytes in the histolysis of Blepharocera and their absence in Holorusia? To my mind, the extent of the metamorphic changes, the degree to which histolysis occurs, probably offers the explanation. In Blepharocera, with its highly specialized larval form, its peculiar and specially developed organs, the change to imago is radical; the histolysis of larval tissues is extensive. In Holorusia, with its generalized larval form, its less modified organs, the change to imago is accomplished with much less breaking down of larval organs and reformation of imaginal ones; the histolysis is less radical and considerable. The phagocytes are the agents or the assisting agents in the more extended and radical histolysis.

My observations so far do not enable me to offer any evidence regarding the moot point touching the causal agency of the phagocytes in histolysis. Whether the phagocytes initiate histolysis, or merely render effective aid after the degeneration has been initiated independently, is a question of importance. 